\title{
A Study of Participation Rate, Transparency and Accountability of Special Autonomy Funds Management in Jayapura
}

\author{
IEK, Mesak \\ Cenderawasih University, Indonesia \\ westim_ratang@yahoo.co.id
}

\begin{abstract}
The aim of this study is to identify and review financial planning and management issues from Papua's Special Autonomy Funds in the fields of education and health over a period of 5 years (2008-2012) in Jayapura and to assess what issues of public concern in that planning and management. The observed object of study is the input, output and outcome of the implementation of the planning and budgeting of Special Autonomy funds related to the services for indigenous people in the education and health sectors in Jayapura. The population in this study is the local work units (SKPD) that manage the funds in both sectors and legislature in the government of Jayapura. The sampling techniques are non-multistage random sampling, non-random and purposive sampling. Data collection is through (1) Questionnaire. (2) Interviews (3) Study of Literature (4) Focus Group Discussion. All the collected date was analysed through the descriptive statistics and case studies. The results show that the medical staff at the health centres (Puskesmas dan Pustu), teachers and principals at the education centres as well as society consider that that level of participation, transparency and accountability in the management of public funds is less satisfactory for indigenous Papuans. Planning through village and district's development planning meetings (Musrenbang) do not get involved health and educational institutions. The community is more involved in the planning process of the Strategic Plans of Village Development (Respek) Funds than the use of special autonomy funds; therefore the information about spending of Respek funds is easier obtained than the government spending on the special autonomy fund. In the compilation of the Proposed Definitive Plan, Development Planning Agency (Bapeda) need to get involved all SKPDs as fund users and the discussion of the Plan needs more consistency in funds allocation of the priority sectors as indicated in the Law 21 of 2001.
\end{abstract}

\section{Keywords: Participation Rate, Transparency, Accountability, Special Autonomy Funds, Management}

\section{Introduction}

The Province of Papua has been part of Indonesia since May 1, 1963 - and even then through the Referendum (Pepera) in 1969. Soon afterwards, the development of Papua continued to be encouraged, however the gap among regions has been a huge issue that cannot be resolved properly in the Republic of Indonesia. The issues of poverty, ignorance, backwardness and isolation of the region cannot be resolved properly in Papua and have resulted in strong public claim to secede from the NKRI. To solve the above mentioned issues, the central government granted special autonomy for Papua province under Law No. 21, 2001. In order to support special autonomy, the central government poured special autonomy fund allocation that continues to increase each year sourced from 2 percent of national DAU added to the infrastructure fund. The allocation of these funds is distributed through Papua province into 29 districts and includes the city of Jayapura. In the period 2002-2012 the amount of funds distributed to the Papua Special Autonomy 33.7 trillion (in rupiahs) and infrastructure funds reached 41.2 trillion (in rupiahs). In accordance with the provisions of Article 34 of Law 21/2001 on Special Autonomy for Papua Province, funds are channelled into the framework of special autonomy should be allocated to build Papuan, especially the indigenous people. The targets of concern are education, health, infrastructure, and economy. These funds are allocated annually from the state budget and transferred to the local treasury belonged by the Government of Papua Province in three or four times also distributed to the districts cities in the province of Papua. Special autonomy funds distributed to Jayapura City since 2002 -2012 reached 520620976400 billion (in rupiahs).

After 12 years, the Papua Special Autonomy was widely criticized where said that the special autonomy funds have not touched the needs of indigenous people. Other critics have claimed that special autonomy funds are 
enjoyed by the elite Papua and do not have impact on the improvement of education and health sectors. There are also sayings that the management of special autonomy funds are not transparent and so on. There are not regulations regarding the financial management of the Special Autonomy to combat the potential corruption and misuse. In the planning and budgeting mechanisms in Papua provincial administration, special autonomy funds received from the Government is distributed $40 \%$ to the province of Papua and $60 \%$ to the district/city. The use of funds managed by the local government district/city is planned through programs and activities on a number of regional work units (SKPD) provided that: (1) the funds should not be budgeted for expenditures apparatus - except for personnel who directly provide services to the community, (2) allocated at least $30 \%$ to the education sector, at least $15 \%$ health, infrastructure, and for the economy. The funds allocated to the city of Jayapura are planned by the government in the budget. To ensure that funds are allocated in accordance with the policies of special autonomy, Bappeda Papua Province needs to take into account the proposed mechanism for the planning of the district/city known as the Proposed Definitive Plan. Each local government received the budget allocation compiles a list of sources of funds use plan prepared by Bappeda district/city and then discussed together in Bappeda Papua Province.

Since 2006, special autonomy funds are also allocated to the villages and districts through the Strategic Plan for Village Development (RESPEK). These funds allocated by the Government of Papua Province are in the form of block grants. The assistance is provided in cash for the planned use in participatory manners by the villagers. The principles of good governance, such as, transparency, accountability, participation, and supervision become mandatory guidelines set in RESPEK program. Residents of the village plan, implement, and supervise each program and activity. Although RESPEK program is considered to have positive impact to promote development from the bottom (bottom-up planning) a number of weaknesses still need to be identified and resolved. The allocation of special autonomy funds allocated every year for education and health in Jayapura should be able to improve services for indigenous people both in 14 villages in 25 subdistricts scattered in 5 districts of the city of Jayapura. However, many people claimed that the assessment of the Special Autonomy funds in Jayapura is not transparent, accountable, participative, less supervised, so it is not the right target. All the above facts then raise question marks and doubts from the community "where is the special autonomy money in Jayapura?" This study is directed to address the financial management issues of special autonomy in health and education, with the expectation that the results of the study will be published in order to be known by the residents and communities.

The main problems formulated in the following research questions: how does the planning and financial management of the Papua Special Autonomy funds on education and health in Jayapura? What problems of public concern in the planning and management of SAF Papua in Jayapura? This study is expected to contribute in the formulation of government policy Jayapura City: to provide complete information about the planning and management of special autonomy funds for education and health; give an input for improved planning and financial management of Autonomy to improve education and health services; to sensitize personnel development planners and special autonomy financial managers on various issues and problems of concern to the financial management community. This study is limited in the scope of the following:

- Planning and management of special autonomy funds for education and health over a period of 5 years (2008-2012), in Jayapura or before PERDASUS No. 25 In 2013, about the distribution and management of funds Autonomy in Papua province.

- The phase of planning focuses on Musrenbang and citizen participation, programs and activities on the education and health priorities.

- The phase of implementation programs and activities focuses on citizen participation, transparency and accountability, implementing human resource competency and supervision activities.

- The phase of administration focuses on qualified financial management, quality and timeliness of reporting.

- The phase of financial records (accounting) and reports focuses on the qualification of financial power, recording expenditures and assets (capital goods), transparency of the results of development;

- The phases of examinations and follow-up examination focus on the qualifications and competence of internal audit (inspectorate), the scope of the examination, and follow-up examination. 


\section{Special Autonomy Fund}

In accordance with Article 34 paragraph 3.e that the Papua Special Autonomy funds are Special amount accepted in the context of implementation of the Special Autonomy equivalent to 2\% (two percent) of the National General Allocation Fund, which mainly is shown to finance education and health; and, f, additional funds for the implementation of Special Autonomy, which amount is set between the government and the Parliament based on the proposal in the province of each fiscal year, which is mainly intended to finance infrastructure development. Furthermore, Article 36 paragraph 2 states that at least 30\% (thirty percent) acceptance in part referred to in Article 34, paragraph 3 is allocated to the cost of education, and at least 15\% (fifteen percent) for health and nutrition. As mandated by Law No. 21 of 2001, the most acute gap in Papua with other Indonesian regions are education and health, in addition to infrastructure and social economy. Therefore, these areas become a priority in the financing of the Papua Special Autonomy Fund. One aspect of LG autonomy is fiscal decentralization. Fiscal decentralization is a process of distribution of funds from the higher levels of government to the lower levels of government to support the delegation of authority and submission of some of the higher level government's affairs to the lower level governments (Ritonga, 2014).

Participation: In budgeting, "participation" implies decision-making regarding policies, programs and activities and the allocation of funds by involving public participation. That attention is an important contributor to accountability". Public participation problems are often encountered in the study of budgeting. Participation is important because it contains the basic aspects of humanity. Everyone wants to be appreciated through the role and participation, and everyone wants to play a part in any activities that directly affect their lives. World Bank research results in NTB and NTT find issues of public participation. The local government's attention to the public proposal is relatively small (only 20-25 percent) (Dimples III Edition 1, November 2004). In NAD public participation in planning and budgeting is still low because of ignorance of how to participate (http: lakaspia.org/ riset01.htm). In Surabaya, Purnamasari (2008) also found the same thing. Low public participation because of regional planning has not focused on the needs of the community. The local government also has not been open in providing information programs and activities. Society only participates in Musrenbang but is not included in the decision-making.

In Papua, the community participation in planning through Musrenbang is still very limited. Even in some districts, Musrenbang villages and districts as mandated regulations are not implemented. Negligence of district administration to organize Musrenbang districts and villages do not receive any attention and supervision from Bappeda Papua Province (World Bank, 2009). At the national level, the implementation of performance budgeting according to the results of Rahayu et al. (2007) has not run as expected. In the present era of public participation is more prominent because of the insistence of the government environmental changes and the emergence of a new paradigm of development. Public budgeting (public budgeting) has received attention from a number of researchers. The implementation of the budget performance has not been formulated "who should be accountable for results, who should hold them accountable, and how." No details, parties should be held accountable and who can force them accountable, to make performance-based budgeting has not been optimally implemented, even if it in developed countries likes the United States and Singapore.

Transparency: Transparency is a deliberate effort to provide all the information that is legally able to release both positive and negative in an accurate, timely, balanced, and decisive ways, in order to improve the ability of public reasoning and maintain the organization's responsibility for the actions, policies, and practices. Furthermore, Political Transparency means the openness in the conduct of all activities of the organization and may include disclosure of information, communication, even in terms of budgeting. Transparency as used in political terms means openness and accountability. Transparent rules and procedures are usually applied to make government officials accountable and to fight corruption. If the government meeting open to the public and the media, the budgets and financial reports can be checked by anyone, where laws, rules and decisions are open to discussion, this will look transparent and will be less likely the government to abuse it for their own interests. After a discussion of the three arms of government, the book discusses subsidiary institutions under the framework of Transparency, Accountability and Corruption. In accord with the general framework, the chapters cover sufficient ground. Overall, the chapters begin with an introduction that 
situates the subject matter and, in most instances, employ case studies to argue their case. The book; notably, discusses watchdog institutions; such as Directorate on Corruption and Economic Crime, Office of the Ombudsman and the Auditor General, and offers recommendations to make them 'bite' because they are believed to be bulldogs with no teeth. Remarkably, the authors use jargon-free language and, therefore, one does not need to be a political scientist, lawyer etc to understand the main concepts. This is the major strength of the book. To this end, this book should appeal to undergraduate students in the social sciences. In addition, it should serve as a reference source for those outside the academia who want to explore issues of Transparency, Accountability and Corruption in Botswana; particularly, members of the public,(Author, Review, Source, \& Url, 2016)

(https://id.wikipedia.org/wiki/Transparansi).

Accountability: Accountability is one of the pillars of the concept of good governance (https://www.google.co.id/akuntabilitas). Accountability allows people to obtain the information they need to assess whether the government's actions are based on important values of good governance, such as effectiveness, integrity, democracy, and transparency. In addition, the Accountability contains a concept of ethics that is close to public administration of government (the executive branch of government, the legislature parliament and the judiciary) which have several meanings such as responsibility, answerability, blameworthiness, liability. In leadership roles, accountability is knowledge and responsibility on each action, product, decision and policy and also including public administration governance and implementation within the scope of the role or position of employment which have an obligation to report, explain and be questioned for every consequence resulted. Accountability is a term associated with governance is actually a bit too broad to be defined. but it often can be described as the relationship between the concerning present or future, between the individual and the group as a liability interest is an obligation to inform, explain to each action and the decision to be approved or rejected or be awarded a penalty when discovered the existence of abuse of authority. https://id.wikipedia.org/wiki/Akuntabilitas. Since not all users of financial statements can understand accounting well, as they will rely on financial information for decision-making, the inability to understand and interpret financial statements should be assisted with the analysis of financial statements. Analysis of financial statements are intended to help understand how the financial statements, how to interpret the figures in the financial statements, how to evaluate financial statements, and how to use financial information for decision-making.(Accounting, 2010)

\section{Methodology}

This research was conducted at the Jayapura City Government, especially at the Department of Education and Department of Health. In accordance with the topics addressed in this study, the aggregate object of the observed studies are inputs, outputs and outcomes of the implementation of the planning and budgeting Papua Special Autonomy funds, related to services for indigenous people in the education and health sectors in the city of Jayapura. Population in this study is the units or SKPDs that manage special autonomy funds in the field of Education and Health as well as the legislature in Jayapura. The sampling technique used is non multistage random sampling. This technique is to take a sample through several stages, until the stage is considered saturated, and carried out non-random. Briefly sampling with this technique can be explained as follows:

The first phase is to determine the sample the units or SKPDs in Jayapura who got the mandate to manage the funds Autonomy in education and health. Secondly, determine the farthest districts which are the sub-district of Muara Tami and Skow Yambe and Holtekamp villages, and Enggros village to represent the South Jayapura district and Yoka village as Heram District as a research target. Samples taken in accordance with the locus of research that represent social organizations, executives and legislature are SKPD, Hospitals, Parliament, and NGOs. While in the village samples taken a representative sample population of primary school, teaching groups, health centers. As for the individual research locus is representative of the population of teachers, doctors, traditional leaders, religious leaders, and households. The sampled households are Papua native, married, and settled in the observation area of maximum 10 years. The method used to take a sample is purposive sampling with criteria that have been set. 
Types of data collected in this study include secondary and primary data. Secondary data is data obtained from the various reports that have been published by a previous institution. While the primary data is data that directly covered on the object observed through specific data collection. The data collected can also be divided into two types of qualitative and quantitative data. Qualitative data is a perception, views or opinions of a person or group of persons related to the subject matter. While quantitative data can be in the form of interval or ratio scale as the number of special autonomy funds allocated for Education and health, economic growth, poverty, Human Development Index, School Participation, Malnutrition figures, and others. According to the source: this data can come from government agencies such as BPS, Bappeda and Department of Education and Health and the data from non-government agencies, such as, donors, NGOs, associations, and other organizations.

The data collection techniques used in this study is: (1) Dissemination questionnaire by providing a set of questions or statements to the person and ask the respondents to answer. Types of questionnaires distributed an enclosed questionnaire, which is presented in the form that respondents were asked to choose the one that suits their understanding, knowledge and experience. (2) In-depth Interviews. The interview is a means used to obtain information directly from the source. The interview method used is guided interview, where the interview guide has been prepared in advance for answering direct informants in accordance with a focus problem. (3) Study of Literature. Literature study was conducted to obtain a number of secondary data as well as numerous empirical studies related to the research problem, which is done by studying the literature and periodic reports (monthly/yearly) available on the object of research. (4). Focus Group Discussion. It is a technique used to uncover the meaning of a group based on the discussion centered on a particular problem. FGD Focus on SKPDs who manage funds Autonomy, religious leaders, women, youth and indigenous.

Quantitative Analysis of Descriptive Statistics: Quantitative descriptive statistics is the application of statistical methods for collecting, processing, presenting, and analyzing quantitative data descriptively. The activities included in this category are data collection; data grouping, the determination of value and statistical functions, as well as the latter include the creation of graphs and images. In this study, quantitative descriptive statistics serve to explain the circumstances, symptoms or problems found in the implementation of the Special Autonomy policy, whether it is sourced on secondary data and primary. Some descriptive statistical methods used in this study include: frequency distribution, crosstab analysis, index numbers, time series analysis, measures of central tendency, correlation and regression models.

Content Analysis: Content analysis used this study is qualitative content, Qualitative content analysis has focused the attention on the content (meaning) of the text in its context. The data used can be oral, written, or electronic forms. The phase content analysis conducted this study were (1) to collect information from the news media web, (2) identify the major phenomena in question, (3) explore the phenomena through observation and discussion of peers, (4) to formulate the main phenomena management of special autonomy funs, and (5) categorizes phenomena in the analysis matrix dimensions.

Concept Mapping: Concept mapping is the process of concept mapping in the form of a flowchart to form a complete understanding and meaning of the set of issues and problems that occur in one context. The idea of mapping the concept is widely used qualitative research because it is considered useful to summarize the qualitative explains that by using concept mapping, text data between 40 to 50 pages can be contained in a single sheet of paper.

Framework Analysis: This analysis begins with observing the planning system implemented in the use of special autonomy funds compiled based on the applicable rules and regulations. Further seen whether there is good integration between planning and budgeting of funding or sourced from Autonomy. The next step is to observe how the implementation of the special autonomy fund budget is done, where there are four aspects that are the focus namely on budget implementation, monitoring and evaluation, administration and accounting, as well as reporting and follow-up. All stages of the use of the special autonomy funds, ranging from planning, budgeting, and the implementation of the budget, it will be seen whether it has used the principles of participation, transparency and accountability. So that will be assessed further on how the 
effective use of special autonomy funds to efforts to improve service to the community Papua native embodied as output, outcome and impact.

\section{Results and Discussion}

Respondent Profile: The characteristics of the respondents in this research are described according to the type of occupation, education level, age group, number of family members, long years of living and poverty status. The following will be displayed as follows. The number of respondents by sex is composed of 64 percent men (37) and women 36 percent (21 people) meaning that gender equality in the response did not differ much. The majority of respondents consisted of farmers $52 \%, 29 \%$ housewives, fishermen and respectively 6.9 percent, 3.4 percent village officials and community leaders at $17 \%$. So the majority of the samples in the study were farmers and housewives as a group of objects as well as the subject of development in the era of Special Autonomy. The level of education of the respondents is that 100 percent respondents have graduated from their education, comprising 38 percent of elementary and high school education, while 21 percent of junior high school education and 34 percent for Diploma/undergraduate. This means that all samples of the respondent have understood the problem investigated.

The number of respondents who live in the District of Muaratami shows 86 percent of respondents s lived more than 14 years. 10 percent of respondents stated that they settle between 10-14 years, while the remaining 35 percent live between 5-10 years. That is, the respondents in this study suggests that they are not new people who inhabit this region and have better understanding about the problems that occurred in Muaratami. Living conditions of the sample are categorized as "poor" and "non-poor", where most of the poor respondents (88 percent) and non-poor respondents only (16 percent). This means that only 16 percent of respondents who have an income of more than 2 million (rupiahs), while as many as 88 percent have incomes under 2 million (rupiahs). This is because the indigenous people are categorized as low-income people (farmers), so for them it is a bit heavy to fulfil their needs and lives in the long term.

The allocations per priority areas of the Papua Special Autonomy: Special autonomy fund allocation in Jayapura always fluctuated mainly SKPDs who received the mandate to manage the funds Autonomy, for example, the Department of Education, Health, Economy and Public Works/infrastructure. The information in the table below shows that in fact the allocation of Special Autonomy funds on education sector in Jayapura is very volatile, namely in 2008 and 2009 reached 30 percent and 31 percent as mandated by the Special Autonomy Law. After 3 years of 2010, the allocation decreased only 26 percent, and in 2012 to 21 per cent. This means that the budgeting process is still "less obedient" to the mandate of the Papua Special Autonomy.

Table 1: Allocations per priority areas of the Papua Special Autonomy

\begin{tabular}{lllrr}
\hline YEAR & \multicolumn{1}{l}{ ECONOMY } & \multicolumn{1}{l}{ HEALTH } & \multicolumn{1}{l}{ EDUCATION } & \multicolumn{1}{l}{ INFRASTRUCTURE } \\
\hline 2008 & 1.600 .000 .000 & 7.208 .990 .350 & 19.029 .050 .000 & $12.950 .000 .000,00$ \\
2009 & 7.297 .200 .000 & $4.725 .000 .000,00$ & $15.320 .468 .000,00$ & $1.144 .969 .000,00$ \\
2010 & 7.819 .290 .350 & $5.817 .314 .550,00$ & $13.472 .579 .100,00$ & $15.624 .413 .000,00$ \\
2011 & 7.561 .358 .120 & $9.173 .550 .000,00$ & $12.950 .000 .000,00$ & $10.368 .386 .320,00$ \\
2012 & 7.818 .415 .500 & $19.029 .050 .000,00$ & $12.954 .741 .950,00$ & $18.217 .687 .100,00$ \\
\hline
\end{tabular}

Special autonomy fund allocation in the health sector since 2008 fluctuated. The allocation of 2009 is very far from what should be allocated, i.e. from 11 percent in 2008 and dropped to 9.7 percent in 2009 . This value is then increased to 18 percent in 2011 but further decreased to 15 per cent according to the mandate of the Special Autonomy. Autonomy actual allocation of funds in the health sector in the last 2 years has been fulfilling the mandate of the Special Autonomy Law. The overall allocation of Special Autonomy priority 
sectors, namely infrastructure, education, health, and economy over the last 5 years shows the development of the fluctuating, only economics almost the relatively small increase in the annual budget.

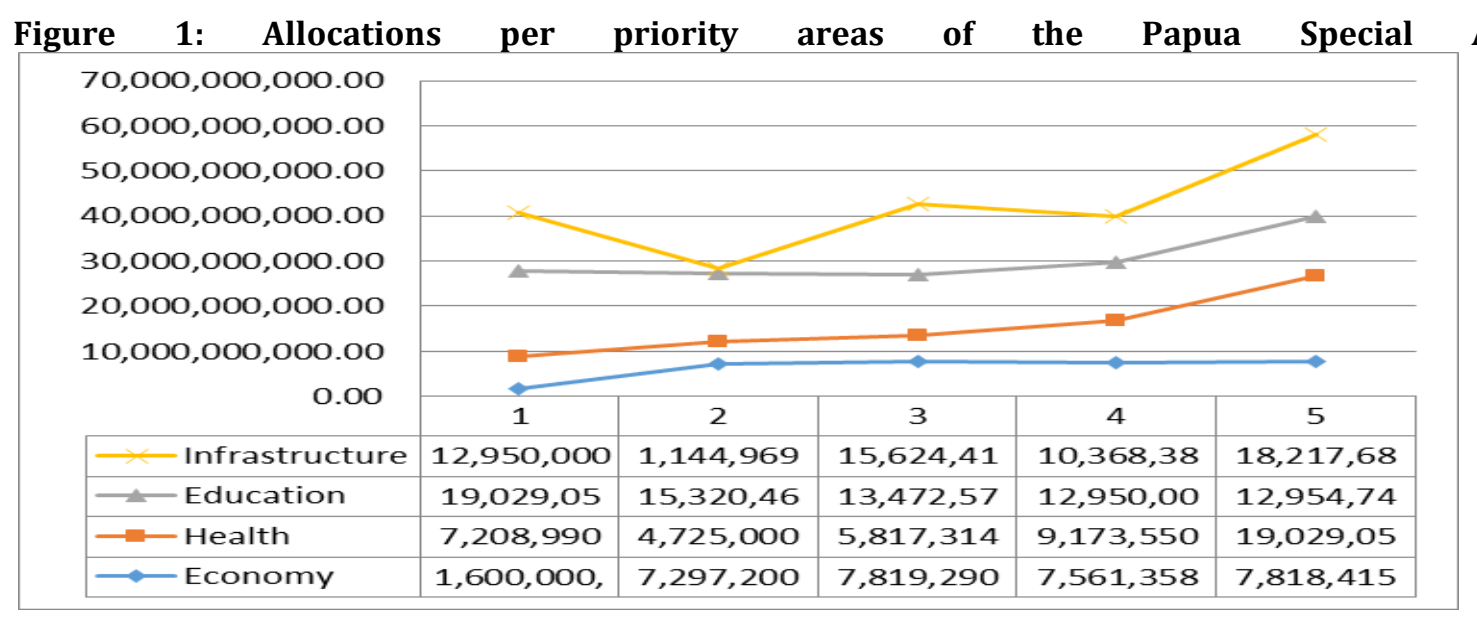

Autonomy

Analysis of Special Autonomy Fund Management in Jayapura: Indicators in the following table guide the analysis of the achievements of the Special Autonomy fund management in the city of Jayapura 2008-2012. Results indicators are becoming a major component of assessment is the level of participation, transparency and accountability in the category are very satisfactory, satisfactory, adequate satisfactory, unsatisfactory, and very unsatisfactory.

Table 2: Respondents Assessment Criteria Weights

\begin{tabular}{llll}
\hline \multicolumn{1}{c}{ Overall Ranking Methodology } & & & \\
\hline Very satisfactory & $80-100 \%$ & 0,80 & $\mathrm{~A}$ \\
Satisfactory & $60-79 \%$ & 0,60 & $\mathrm{~B}$ \\
Adequate satisfactory & $40-59 \%$ & 0,40 & $\mathrm{C}$ \\
Unsatisfactory & $20-39 \%$ & 0,20 & $\mathrm{D}$ \\
Very unsatisfactory & $00-19 \%$ & 0,00 & $\mathrm{E}$ \\
\hline
\end{tabular}

Analysis of the Special Autonomy Fund Management: The picture below explains WEB achievement total of special autonomy management in Jayapura. In general aspects of participation, transparency and accountability are very satisfactory meaning that the special autonomy fund management is very participatory, Transparent and accountable. However, the assessment from the SKPDs, Institutions and Society is varied and different.

Fig. 2: The assessment of special autonomy funds by SKPDs

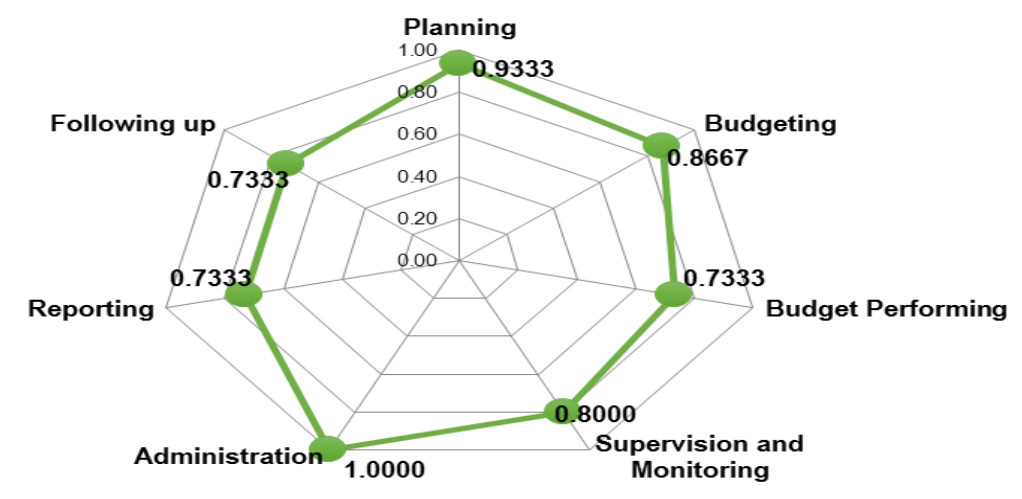


Under the WEB management of funds Autonomy by rating SKPDs as implementers shows that from 7 aspects of management, there are four aspects that reached a value above 79 percent or achieve "A" i.e. planning, budgeting, administration and supervision and monitoring, while the remainder of each 73 percent, meaning that the management of SAF in Jayapura in total is very good in terms of planning, budgeting, budget execution, supervision and monitoring, administration, reporting and follow-up if there are findings. According to SKPD that all regulations for managing the special autonomy fund has been set by the provincial government and its implementation carried out by SKPD in the city. This is also reflected in the delivery of the project to entrepreneurs native Papua. They with good track record will be fostered in order to get the project.

Further assessment of the community as beneficiaries, it was not as good as on SKPDs' assessment. Only the aspects of planning who scored in the top 60 or 73 percent, while as many as two aspects scored below 40 percent, which is the follow-up of 31 percent and 25 percent internal examination. It means that today's society assess the results of the audit oversight bodies or agencies have been no follow up and internal supervision. The same assessment also occurs in health and educational institutions receive the same value $\mathrm{C}$.

\section{Fig. 3: The assessment of special autonomy funds management by community and institutions}
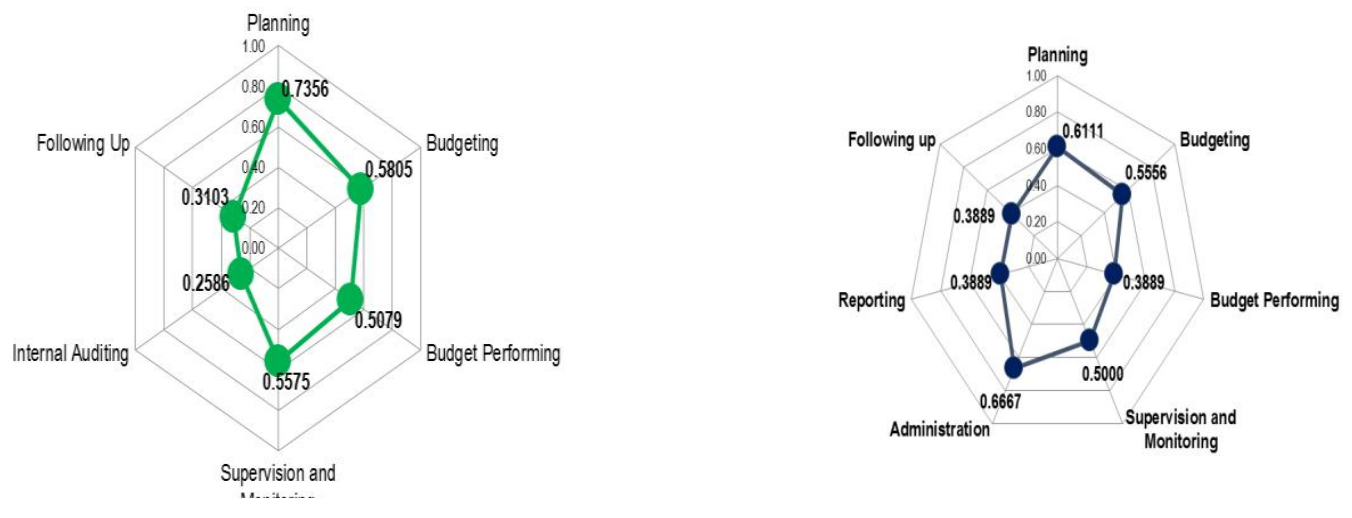

Participation: The analysis showed that the level of participation in planning use of special autonomy funds at SKPD level in Jayapura showed the 100 percent or very satisfactory. This means that from the aspect of planning, the use of funds has been very good. The same thing happened in the aspect of follow-up showing the same figure, it means that follow up on the findings of the CPC is very good. Budgeting, implementation and supervision to reach 80 per cent is very good. This is evidenced by the results of interviews with the respondents as follows: "The level of participation in the SKPD, always involves indigenous Papuans in the preparation of planning activities that use special autonomy funds, especially 8 indigenous Papuans in SKPD, but not all of the special autonomy fund used for activities touch them and until now there is no mechanism for public complaints, and usually only in internal SKPDs. (Secretary of the City Health Office, Secretary of Bappeda) ". 
Fig. 4: WEB assessment of the participation level by SKPDs, community and institutions
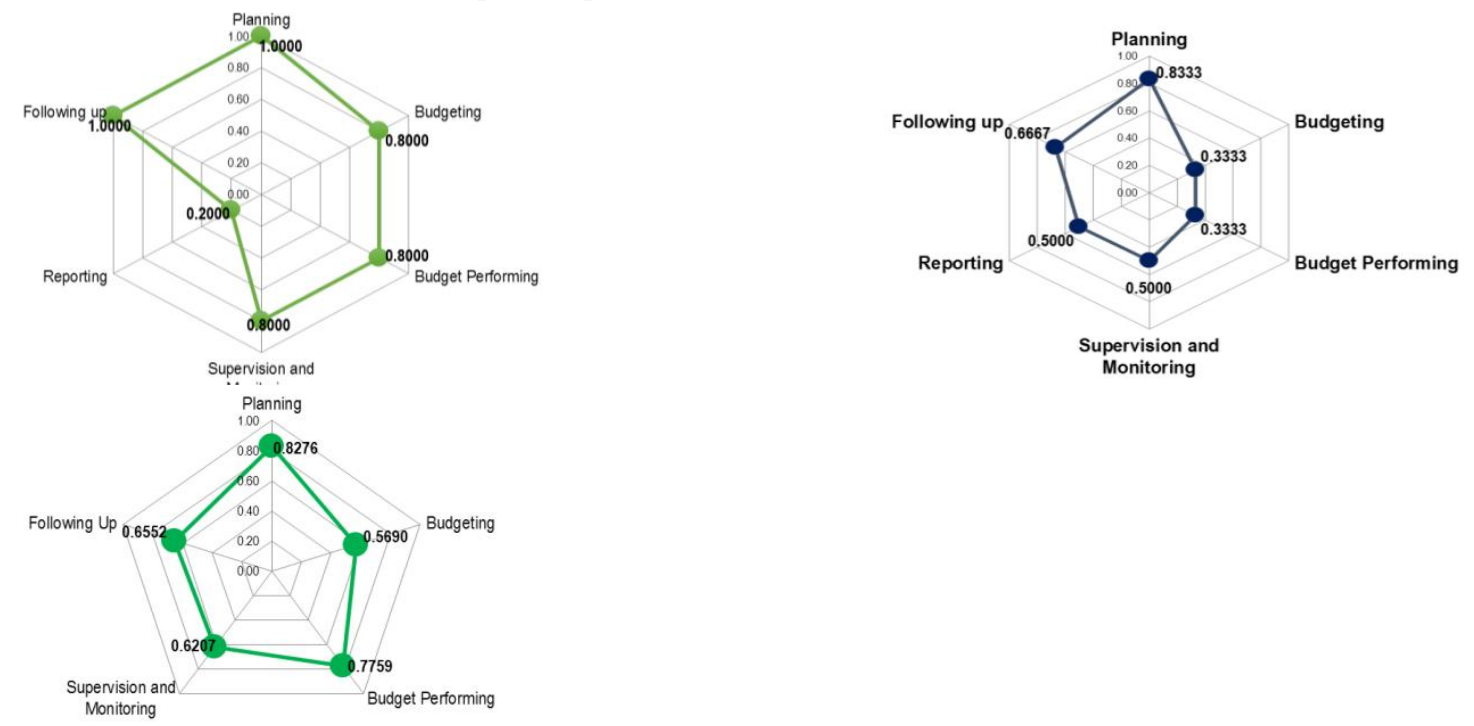

The same is followed on the aspects of follow-up showed the same figure; it means that the follow up on the findings of the BPK is very good. Budgeting, implementation and monitoring showed 80 percent figure meaning very good values. Furthermore, reporting and internal control aspects fund management Autonomy scored 20 percent means very unsatisfactory. This means that participation in reporting and internal Controls are very bad at SKPD level. This is of concern to the fore in the process of implementation of the special autonomy fund budget in Jayapura. The aspects of participation from the management of funds at SKPD reached Achievement (B), it is said to be good. The best thing on the participatory aspect is the planning, follow-up, budgeting, budget execution and monitoring and evaluation.

Participation of the people of Papua in Jayapura in the planning and management of development is pursued more institutionalized, so that development plans and programs can be tailored to local needs and diverse group, which ultimately enable a more realistic and effective programs. The data processing questionnaires on public opinion, health agencies, in Jayapura against public participation is done in the planning, implementation and supervision in governance and implementation of development through the participation of representatives of indigenous, religious, youth, groups of local business and women can be seen in the following discussion. The following will be displayed WEB Level Muaratami District Public participation in running the programs and activities funded by Special Autonomy Fund. At the stage of preliminary planning is done by the local government in finding, knowing, formulating whatever the community needs to be programs and work activities expected to be the welfare of society. Questions are given to obtain public perception of fund management Autonomy of planning in the city of Jayapura, i.e. whether they were invited to attend the Musrenbang at district or village level administration. From the results of the survey of the community, it achieved B. This achievement reflects the level of community participation involved to plan programs and activities stemming from the use of funds. In the government there are agency between legislative and government (Halim \& Abdullah, 2006). This means Musrembang that has been done already involved the entire community in the city of Jayapura. The management aspect that is not optimal to focus on the management of this participation from the stage is "Budgeting, Control and Monitoring, and Follow-up. It is expected that in the future, these aspects pay more attention on improvements in order to improve the public service native Papua in Jayapura.

Transparency: SKPD assessment of the level of participation in planning and budgeting earmarked from the Institute of Education and Health ranks C (adequate satisfactory). The worst assessment in Follow-up reaches 17 percent or highly unsatisfactory. This is according to the institution that the follow-up of the special autonomy fund management issues has lack of response. Therefore, in the future it requires attention and improvement. Furthermore, the assessment of individuals representing the community does not differ much 
with the assessment of the institution. Public assessment of the level of transparency in the planning stages reaching a score of 0.6897 , or 68.97 percent, this achievement illustrates the planning stages of programs and activities financed from special autonomy funds pretty good or satisfactory, for example, Musrenbang in Jayapura has been implemented fairly open to all components of society. The next focus of management that contributes to the greatest degree of transparency is only on Supervision and Monitoring that achieve a score at 0.8276 or 83 percent. The rest achieved a score below 60 percent. This is very evident with the achievements Achievement C. This means that the transparency of the management of funds for the Special Autonomy in Jayapura in view is quite satisfactory. There are several management focus that still needs serious attention, especially in the aspect of transparency such as, follow up $(12,1 \%)$, and execution $(37,9 \%)$. Jayapura City Government really needs to follow up on any findings on the use of Special Autonomy funds that have not been targeted; in addition, they need consistency of implementation of the budget in accordance definitive plan agreed with the Agency Papua Province.

\section{Fig. 5: WEB assessment of the transparency level by SKPDs, community and institutions}
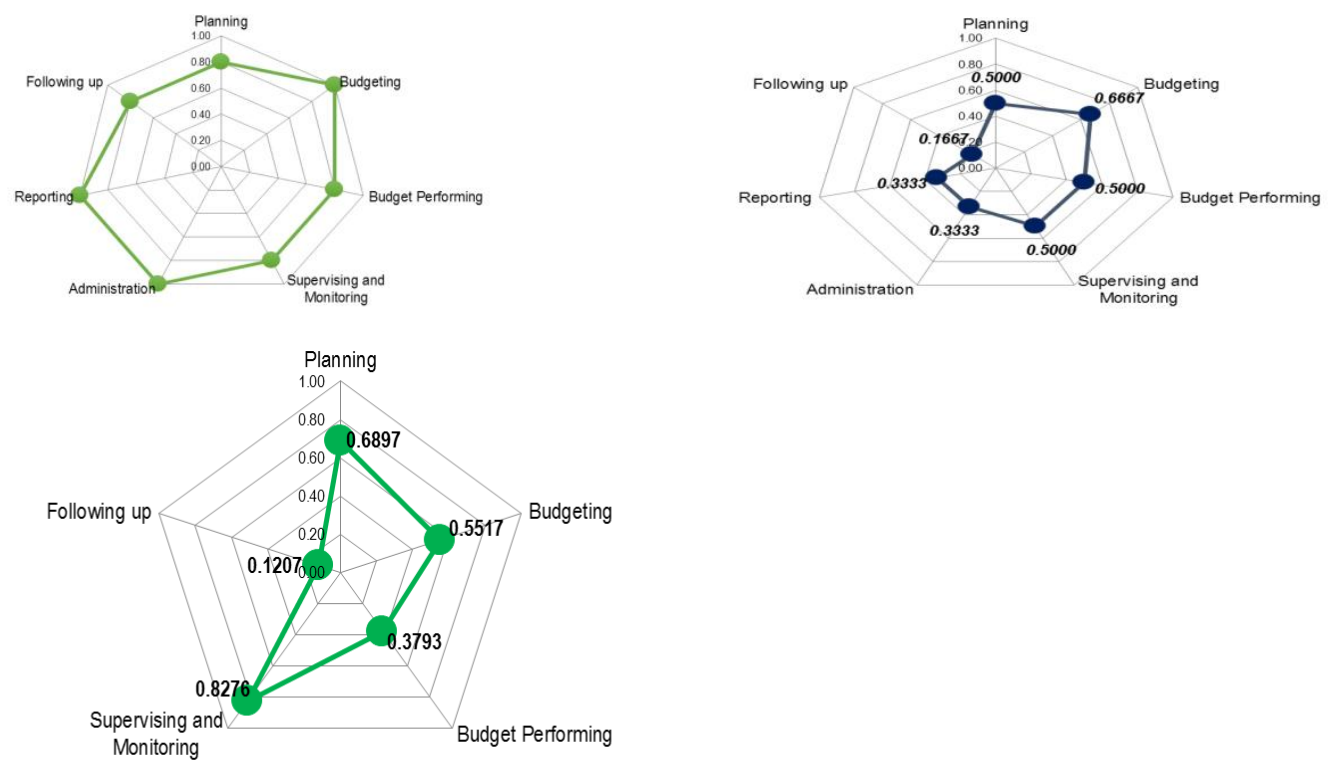

Assessment of the community as beneficiaries of special autonomy fund expenditures needs more concern for future improvements and the problem resolution for Papuan people handled properly and seriously. Furthermore, the level of transparency of the seven aspects according to SKPD is very well and got ratings of 80 to 100 percent or A. That is the judgment of SKPD that the special autonomy fund management in Jayapura has been very transparent in the review of the seven aspects assessed.

Accountability: Accountability is a concept of good governance that can enable people to obtain the information they need to assess whether the government's actions are based on important values of good governance, such as effectiveness, integrity, democracy, and transparency. Accountability can bridge the information gap between local governments and the public. Little information gaps will improve communication between local government and the public so as to produce a good relationship and push for the creation of a public trust to local governments. Therefore, accountability can be used by local governments to demonstrate their legitimacy in order to gain support from the community.

Analysis of the regional work units (SKPDs): From the results of the overall analysis, the focus of the special autonomy fund management for Accountability in SKPD in the preparation of Planning and Budgeting, Execution of Budget, Oversight and Monitoring, Administration, Reporting and Follow-up engagement on education, the results of the analysis shows the average opinion of SKPD at $0.800(0.80)$ with satisfactory (A). According to the assessment of SKPDs that accountability in the process of planning, administration and reporting reaches 100 percent or very good value. Furthermore, budgeting, supervision and monitoring of the 
implementation of the special autonomy fund reaches 80 percent. It means that these two aspects show satisfactory results. This is evidenced by the achievement of 80 per cent with the achievement of "A". While the follow-up aspects in terms of the accountability reached a value of $40 \%$ or quite satisfactory. These aspects need attention.

Analysis of the Institute: Education and health institutions in the city of Jayapura in aspects of the management of special autonomy funds for participation, education and health institutions opinion show value $\mathrm{C}$, it is shown on the WEB at the top. The following will describe each aspect as follows. Aspects of participation from the management of special autonomy funds reached a value of 0.571 with (C), then it is said to be adequate satisfactory. The most excellent in the aspects of the participation is planning and Administration while the other focus is under 6 percent. In the aspect of management transparency of special autonomy funds reached a value of 0.429 with the value of $\mathrm{C}$, it can be said Adequate Satisfactory. Management focus on the aspect that gets good value is the budgeting aspect at 0.6667 , while the aspects of planning, budget execution, supervision and monitoring each received value at 0.5000 . The rest focus gives unsatisfactory value.

Furthermore, accountability achieves value at 0.500 then the achievement is $C$. The aspect of management accountability which contribute very satisfying is on the management of Administration at 0.8333 , followed by budgeting $=0.666$. While other management focus only under 0.500 . This condition if associated with sample data field at the institution states that: "Every year we received a budget allocation of Special Autonomy funds, but only once involved in the planning process. And the cost of which is used to build the health sector is never delivered or reported to us in the clinic". "Furthermore, the sample of education stated that in terms of participation in planning "when Musrenbang in the district should we be invited to express the thought of the world of education/work program". We have never been involved in the preparation of the program but are only required to input proposal only ". This condition reflects that Musrenbang villages and districts do not get involved all stakeholders, especially the institutions as users of special autonomy funds. This is a concern especially the special autonomy fund managers at related SKPDs.

Analysis of Society: From the survey results can be seen scores achieved by 0.3861 , or 38.61 per cent for public review, and performance achieved is Rated "D". That is the level of accountability of the management of special autonomy funds in Jayapura show unsatisfactory. The achievement reflects the level of accountability of governments to provide information and data that is "unsatisfactory" to the general public, especially information concerning the special autonomy fund management reporting to the general public. That is reporting against the use of special autonomy funds in the sample areas are not accountable to the public. In other words that the information about the management of special autonomy funds is not published. The management aspect that is not optimal at Focus Management at the stage of accountability is "Follow Up" (0.1552), Supervision and Monitoring (0.2241), Internal Inspection (0.2586). This means that accountability is still not considered to be the needs of the community by local governments.

Fig. 6: WEB assessment of the accountability level by SKPDs, community and institutions
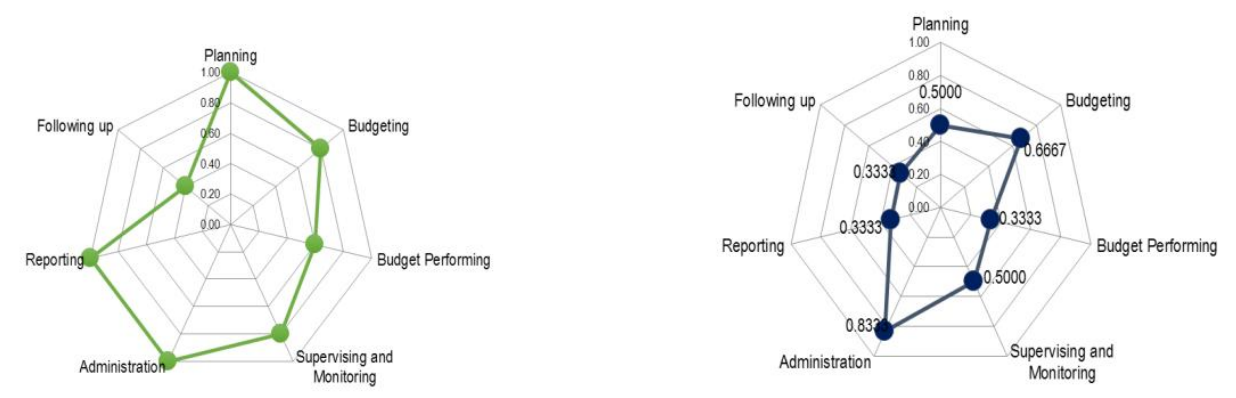


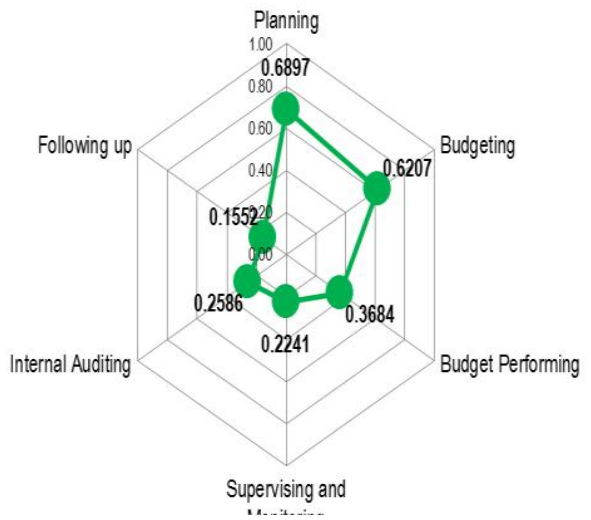

\section{Conclusion}

- According to the Rating Agencies and Communities that the level of participation, transparency and accountability in the management of special autonomy funds tend to be less satisfactory in Jayapura for indigenous community as objects. Planning done through Musrenbang villages and districts do not get involve health and educational institutions in the planning process.

- People tend to be more involved in the planning process of Respek than the use of special autonomy funds.

- Information about the Respek spending is easier obtained by the public than the government spending Using special autonomy fund.

- People who live in suburban Jayapura less know about special autonomy funds for indigenous Papuans.

\section{Recommendation}

- It is necessary to involve all users of special autonomy funds to conduct the planning from Musrenbang village and district to city level.

- In the compilation of proposed definitive plan, Bapeda need to involve users of Special Autonomy funds on education and discussion of the plan is very necessary to have the consistency of allocations to priority sectors mandated in Act 21 of 2001.

- For information disclosure, each user's special autonomy funds shall provide information about the amount of funds and activities financed by special autonomy funds through the media information such as information boards or leaflets, newspapers, radio and local television to the public.

- Jayapura government needs to regulate the management of special autonomy funds to accommodate to needs of indigenous Papuans.

\section{References}

Accounting, P. S. (2010). The Influence of Financial Performance to the Level of Accountability Disclosure of Indonesia's Local Government Master of Accounting Faculty of Economic Level of Accountability Disclosure of Indonesia' Local Government.

Author, R., Review, E. B., Source, E. B. \& Url, S. (2016). Author(S): Emmanuel Botlhale Review By. Emmanuel Botlhale, 41, 140-142.

Ritonga, I. T. (2014). Analysing Service-Level Solvency of Local Governments from Accounting Perspective : A Study of Local Governments in the Province of Yogyakarta Special Territory, Indonesia.

Halim, A. \& Abdullah, S. (2006). Hubungan dan Masalah Keagenan di Pemerinta-han Daerah: Sebuah Peluang Penelitian Anggaran dan Akuntansi.

https://id.wikipedia.org/wiki/Transparansi_\%28politik\%29

https://id.wikipedia.org/wiki/Transparansi

Purnamasari, I. (2008). Studi Partisipasi Masyarakat Dalam Perencanaan Pembangunan di Sukabumi. Disertasi. UNDIP. 
Rahayu, S., Ludigdo, U. \& Affandy, D. (2007). Studi Fenomenologis Terhadap Proses Penyusunan Anggaran Daerah : Bukti Empiris Dari Satu Satuan Kerja Perangkat Daerah di Provinis Jambi. Simposium Nasional Akuntansi X, Unhas Makassar 26-28 Juli 2007.

World Bank. (2009). Kajian Pengeluaran Publik - Provinsi Papua: Dinamika Pengelolaan Keuangan Daerah dan pelayanan Publik Dalam Suatu Provinsi Otonomi Khusus Hasil Studi Public Expenditure Analysis. Kerjasama Bank Dunia Pemda Provinsi Papua, dan Pusat Kajian Ekonomi dan Keuangan Daerah Uncen, Jayapuras. 